\title{
Nutritional Values of Tung Samrit Jasmine Rice for Geographical Indication in Nakhon Ratchasima Province
}

\author{
Wassana PHANURAK
}

Faculty of Science and Technology, Nakhon Ratchasima Rajabhat University, Nakhon Ratchasima 30000, Thailand

(Corresponding author's e-mail: wasnt23@hotmail.com)

Received: 9 January 2020, Revised: 24 April 2021, Accepted: 30 April 2021

\begin{abstract}
The nutrition values of jasmine rice, i.e., Khao Dowk Mali (KDM) 105, from the Tung Samrit area covering 14 districts of Nakhon Ratchasima province of Thailand, were analyzed during the production seasons in 2015 and 2016. The analyzed values involved moisture, carbohydrate, protein, fat, energy, ash, vitamin E, vitamin B1, niacin B3, iron, zinc, and 2-acetyl-1-pyrroline (2-AP) contents. One of the values, 2-AP, a major aroma compound, showed significantly higher the other kinds of rice $(2.71 \pm 0.05$ (mg/100 g)). The comparison to the literature suggests that the rice product from the Tung Samrit area is up to the national standard. In addition to the use in the documentation for the geographical indication (GI) registration, the collaborated plans and policy were derived with the participation of farmers, dealers, and government agencies to promote sustainable "Tung Samrit jasmine rice".
\end{abstract}

Keywords: Food Valley, Jasmine rice, Northeast Thailand, Nutritional value, Tung Samrit area

\section{Introduction}

Jasmine rice is the major agricultural product of Nakhon Ratchasima province in northeast Thailand. Around $92 \%$ of the total 7,000 square kilometers $\left(\mathrm{km}^{2}\right)$ rice fields in this province are in the Tung Samrit area, covering 14 districts [1]. Although the farmers have continually been supported by government agencies in rice production, several problems are currently affecting the quantity and quality of the outputs. Wrong practices of farmers for maintenance and development of rice quality, based on good agricultural practice (GAP), have led to substandard rice productions. The use of excessive fertilizers degrades soils and adversely affects the health of farmers and consumers. Climate change have also caused a water shortage during the planting season and increases temperatures and insect outbreaks. The shortage of labor has changed the production system into contract machining. Consequently, the production cost has inevitably been higher whereas the yield per $\mathrm{km}^{2}$ seems to have declined. In the 2015 season, the average production cost was about $110 \mathrm{~km}^{2}$. Besides, the community enterprise in the processing of rice products has been lacking and local farmers mostly sell their products as paddy.

Nakhon Ratchasima Provincial Agriculture Office has realized the urgency to implement knowledge, adjust the attitude of farmers, and seize opportunities for sustainable community-based agriculture. The 4-year development plan of Nakhon Ratchasima is aimed at both high technology and agricultural industry. The province will be designated as a "food valley", especially for rice. Area-based collaborative research and developments are very important to reach this goal. This requires the integration of resources and cooperation of all sectors including government agencies, private sectors, academics, and local communities. By strengthening and empowering the community, each area can appropriately be developed based on the local context. With a common direction, all other sectors will participate in problem-solving and the government services will efficiently meet the needs of community

Walailak J Sci \& Tech 2021; 18(14): 9352 
members. This collaborative approach is in contrast to the traditional conducts relied solely on functional government agencies with the top-down mission.

This work integrates all sectors to promote sustainable "Tung Samrit jasmine rice". It is initially driven by the nutritional value of Thai jasmine rice. A GI is often used on a product that has a specific geographical origin with quality, reputation, and characteristic. With the scientific evidence, the policy and action plan for its value addition can be mutually settled based on the apparent potential of the local jasmine rice. As a crucial part of the food valley, the quality of product will be increased and become competitive in the global market.

\section{Materials and methods}

Rice collection and sampling sites

The current study collected the Tung Samrit jasmine rice (Oryza sativa KDML 105) from the Tung Samrit area of Thailand, from 2015 to 2016 . Each rice sample (3 kg) was collected from 14 areas, pooled, and then, divided into 3 parts for analysis. Figure 1 illustrates that the approximate area of $6,417 \mathrm{~km}^{2}$ covers 14 districts, namely Bua Yai, Bua Lai, Sida, Lam Thamenchai, Mueang Yang, Khong, Chakkarat, Chum Phuang, Prathai, Phimai, Chaloem Phra Kiat, Non Sung, Non Daeng and Huai Thalaeng.

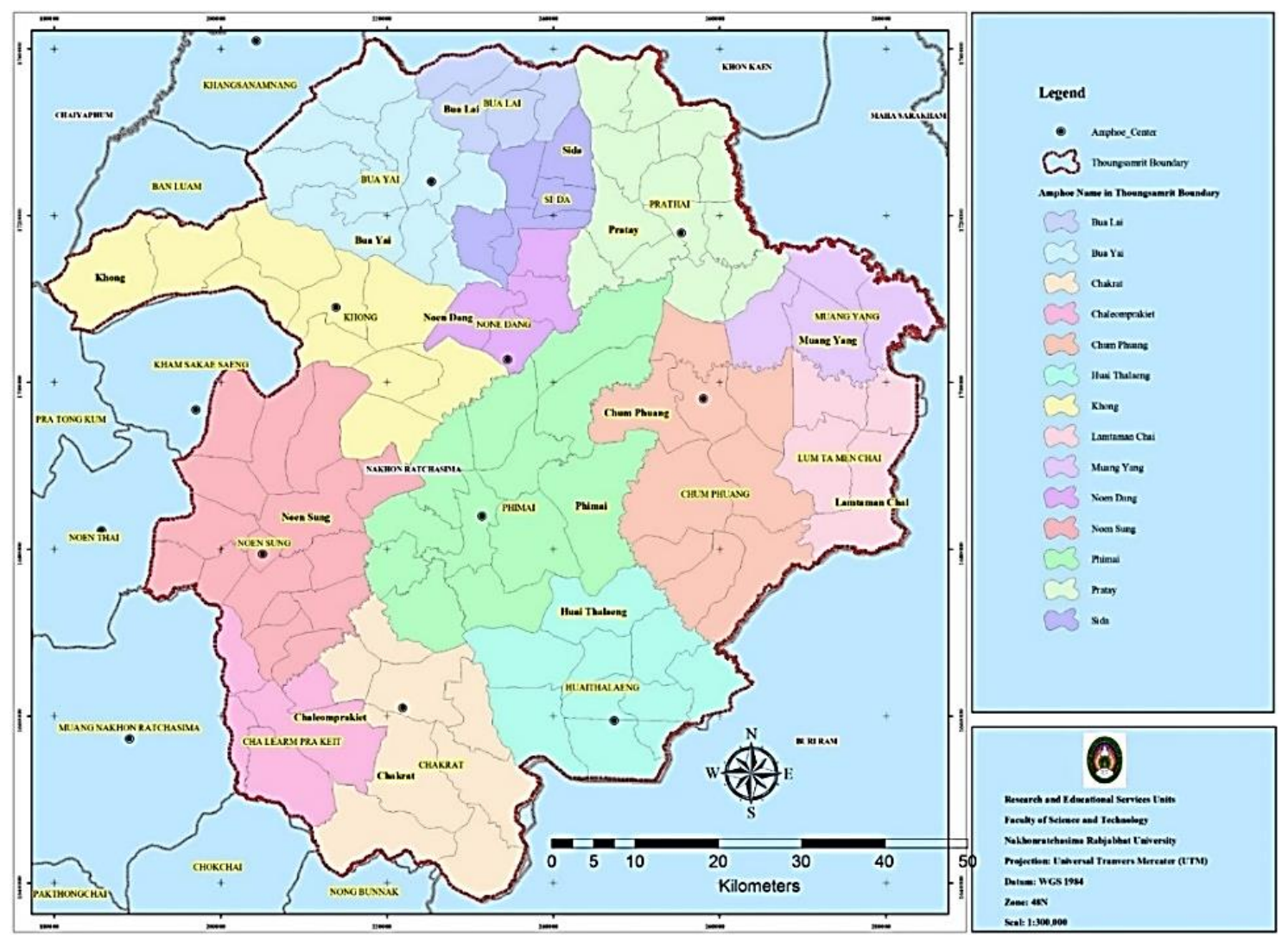

Figure 1 The map of the Tung Samrit area covering 14 districts of Nakhon Ratchasima. 


\section{Analysis of nutritional values}

The contents of moisture and ash were analyzed according to the guideline by AOAC [2] with protein according to the guideline by International Association for Cereal Science and Technology (ICC) [3]. Vitamin E in the forms of alpha-tocopherol was measured with HPLC [4] whereas Vitamin B was measured according to the Thiochrome method by using Spectrophotometry [5]. Niacin was determined by using a Microbiological assay [6]. Minerals, i.e., iron and zinc, and 2-acetyi-pyrroline were respectively measured by using Atomic absorption spectrophotometry and CGMS [7]

The social science knowledge and scientific knowledge about the local wisdom on management and promotion of Tung Samrit jasmine rice was also integrated for supplying information for the GI registration. The characteristics of Tung Samrit jasmine rice from 14 districts were presented to the focus group consisting of farmers, dealers, and government officers. By exchanging information and idea, the policy and action plans can be established to strengthen the production and fulfill the potential of "Tung Samrit jasmine rice".

\section{Results and discussion}

Nutritional values and characteristics of Tung Samrit jasmine rice

Table 1 depicts the average of the nutrient values of Thai jasmine rice KDML 105 from 14 districts in the Tung Samrit area. Small standard deviations (SD) indicate that the qualities of products from different districts are comparable. Compared to other areas, the nutritional values were comparable to those previously reported by domestic [8,9] and international researchers. 2-AP showed significantly higher than other kinds of rice $(2.71 \pm 0.05(\mathrm{mg} / 100 \mathrm{~g}))$. These results indicate that Tung Samrit jasmine rice can be standardized. Additionally, the report on the soil analysis in Nakhon Ratchasima province by Lertna [11] supported that the Tung Samrit area was suitable for rice production.

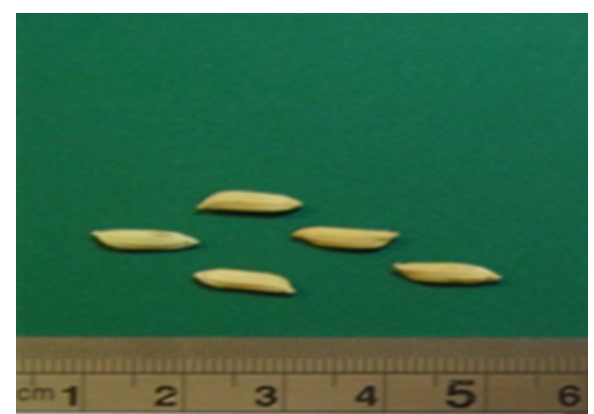

(A)

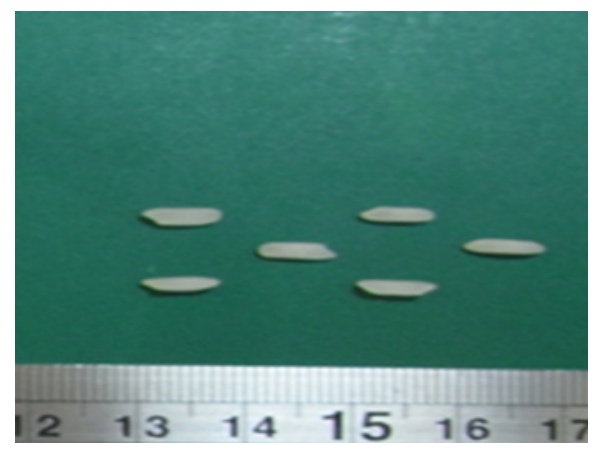

(B)

Figure 1 Characteristic of Tung Samrit jasmine rice, unhusked rice (A), white rice (B). 
Table 1 Nutritional value comparison of Tung Samrit jasmine rice with other rice cultivars.

\begin{tabular}{|c|c|c|c|c|c|c|c|c|}
\hline \multirow{2}{*}{ Nutritional values } & \multicolumn{8}{|c|}{ Rice cultivars } \\
\hline & $\begin{array}{l}\text { Tung Samrit } \\
\text { jasmine rice }\end{array}$ & Rice & Rice & $\begin{array}{l}\text { Nige-ria } \\
\text { rice }\end{array}$ & Rice & $\begin{array}{c}\text { Mahsuri } \\
\text { mutant rice }\end{array}$ & $\begin{array}{l}\text { Kpurukpuru } \\
\text { Afikpo rice }\end{array}$ & Basmati rice \\
\hline $\begin{array}{l}\text { Moisture } \\
(\mathrm{g} / 100 \mathrm{~g})\end{array}$ & $11.36 \pm 0.04$ & - & 17.6 & $7.68 \pm 7.09$ & $7.95 \pm 1.93$ & $10.72 \pm 0.16$ & 10.00 & - \\
\hline $\begin{array}{l}\text { Carbohydrate } \\
(\mathrm{g} / 100 \mathrm{~g})\end{array}$ & $75.30 \pm 0.13$ & - & - & - & - & $73.20 \pm 0.29$ & - & - \\
\hline $\begin{array}{l}\text { Protein } \\
(\mathrm{g} / 100 \mathrm{~g})\end{array}$ & $7.60 \pm 0.04$ & 7.5 & 1.8 & $4.99 \pm 1.38$ & $13.00 \pm-3.32$ & $10.69 \pm 0.12$ & - & $5.62 \pm 0.14$ \\
\hline $\begin{array}{c}\text { Fat } \\
(\mathrm{g} / 100 \mathrm{~g})\end{array}$ & $4.02 \pm 0.02$ & 2.8 & 7.6 & $1.90 \pm 1.03$ & - & $2.79 \pm 0.01$ & 2.23 & - \\
\hline $\begin{array}{c}\text { Energy } \\
\text { (calories) }\end{array}$ & $357.47 \pm 0.27$ & - & 345 & $369 \pm 27.87$ & - & - & - & - \\
\hline $\begin{array}{c}\text { Ash } \\
(\mathrm{g} / 100 \mathrm{~g})\end{array}$ & $0.54 \pm 0.00$ & 1.1 & - & $0.99 \pm 0.42$ & $10.60 \pm 2.81$ & $1.63 \pm 0.01$ & 0.80 & - \\
\hline $\begin{array}{l}\text { Vitamin E } \\
(\mathrm{mg} / 100 \mathrm{~g})\end{array}$ & $0.504 \pm 0.01$ & 0.7 & - & - & - & - & - & - \\
\hline $\begin{array}{l}\text { Vitamin B1 } \\
(\mathrm{mg} / 100 \mathrm{~g})\end{array}$ & $0.56 \pm 0.01$ & 0.25 & 0.34 & - & - & - & - & - \\
\hline $\begin{array}{l}\text { Niacin B3 } \\
(\mathrm{mg} / 100 \mathrm{~g})\end{array}$ & $9.55 \pm 0.29$ & & & - & - & $4.97 \pm 0.00$ & 1.81 & - \\
\hline $\begin{array}{c}\text { Iron } \\
(\mathrm{mg} / 100 \mathrm{~g})\end{array}$ & $1.09 \pm 0.02$ & - & - & - & - & $1.80 \pm 0.00$ & 1.15 & $2.7 \pm 0.07$ \\
\hline $\begin{array}{c}\text { Zinc } \\
(\mathrm{mg} / 100 \mathrm{~g})\end{array}$ & $2.96 \pm 0.02$ & 0.37 & - & - & - & - & 9.81 & - \\
\hline $\begin{array}{l}\text { 2-acetyl-1-pyrroline } \\
\text { (mg/100 g) }\end{array}$ & $2.71 \pm 0.05$ & - & - & - & - & - & - & - \\
\hline References & $\begin{array}{l}\text { This } \\
\text { work }\end{array}$ & [8] & [9] & [11] & [12] & [13] & [14] & [13] \\
\hline
\end{tabular}

\section{Collaborative plans to promote Tung Samrit jasmine rice}

The nutritional values of rice in the Tung Samrit area, Nakhon Ratchasima, were exposed as a starting point for the promotion of Tung Samrit jasmine rice. The quantitative results combined with the characteristic aroma and softness highlighted in this study can be associated as the identity of Tung Samrit jasmine rice in the niche market. For a successful operation, the policy needs support from the public, private, and academic sectors. As an example, the policy regarding chemical use must be implemented since safety is a key target in rice production, consumption, and trade. The whole process must comply with the conditions of the market and consumer demand. However, the production of rice still relies on chemical use in some areas, including the Tung Samrit area. Collaborative action can resolve this problem and the production cost can be decreased with the reduction in chemical use. Furthermore, the nutritional values are used in the submitted document for GI registration which was not able to complete in the past. The value addition to Tung Samrit jasmine rice is then created, consistent with the Nakhon Ratchasima development plan to become the food valley and the kitchen of the world in the future. Moreover, multidimensional ecological agriculture led by framers organization would be practiced to promote jasmine rice production of Thailand to excel at the domestic and the international market. 
http://wjst.wu.ac.th

\section{Conclusions}

In response to an urgent need to promote jasmine rice for Nakhon Ratchasima province, rice samples cultivated from 14 districts in the area of Tung Samrit were examined. Their nutritional values, especially 2-AP, were comparable and up to the national standard. GI rice prices are higher than other non-GI rice. The results were further used in the area-based research collaborative research to enhance the quality and value of the products. The obtained policy and actions fittingly support the food valley development plan.

\section{Acknowledgements}

The authors acknowledge the financial support provided by the National Research Council of Thailand under the NRCT 2015 research scholarship.

\section{References}

[1] W Phanurak. Cooperation to promote rice production safety to food security and increase the family income according to sufficiency economy, Nakhon Ratchasima. Office of Thailand Research Fund, 2013.

[2] P Cunniff and Association of Official Analytical Chemists. Official methods of analysis of AOAC international. Association of Official Analytical Chemists, Washington DC, USA, 1995.

[3] ICC Standard methods No 105/2 Determination of Crude Protein in Cereals and Cereal Products for Food and Feed, Available at: http:://www.icc.or.at, accessed October 2019.

[4] MI Heinonen, V Ollilainen, EK Linkola, PT Varo and PE Koivistoinen. Carotenoid in finish foods: Vegetables fruits and berries. J. Agri. Food Chem. 1989; 37, 655-69.

[5] WC Ellefson. Methods of vitamin assay. $4^{\text {th }}$ ed. A Wiley Interscience Publication, USA, 1985.

[6] G Angyal. Method for the microbiological analysis of selected nutrients. Association of Official Analytical Chemists, Maryland, USA, 1996.

[7] AB Nadaf, S Krishnan and KV Wakte. Histochemical and biochemical analysis of major aroma compound (2-acetyl-1-pyrroline) in Basmati and other scented rice (Oryza sativa L.). Cur. Sci. 2006; 91, 1533-6.

[8] P Rujirapisit, W Sangkaeo and S Ieowsakulrat. Nutritional value of 9 rice cultivars. Agric. Sci. J. 2012; 43, 173-6.

[9] S Tongpian. Aromatic rice varieties and standards of rice in Thailand. Rice Research Institute, Department of Agriculture, Ministry of Agriculture and Cooperatives, 2005.

[10] S Lertna, T Sethaphayak and B Varinruk. Rice production potential zoning of Nakhon Ratchasima provinces. In: Proceedings of the Research Annual Conference 2008, Northeastern Region Rice Research Center Group, Sakon Nakhon, Thailand, 2008.

[11] A Oko, B Ubi, AA Efisue and D Nahemiah. Comparative analysis of the chemical nutrient composition of selected local and newly introduced rice varieties grown in Ebonyi State of Nigeria. Int. J. Agric. For. 2012; 2, 16-23.

[12] N Ambreen, N Hanif and S Khatoon. Chemical composition of rice polishing from different sources. Pak. Vet. J. 2006; 26, 190-2.

[13] A Rosniyana, NH Ajimilah, RI Hajar and SAS Norin. Chemical composition and physico-chemical properties of Mahsuri mutant and Basmati rice. MARDI Res. J. 1995; 23, 177-81.

[14] IC Alaka, JOS Ituma and FC Ekwu. Physical and chemical properties of some selected rice varieties in Ebonyi state. Nig. J. Biotech. 2011; 22, 40-6. 